\title{
Morphological and physiological responses of two species of Capsicum (Capsicum annuum L. and Capsicum chinense Jacq.) under conditions of water deficit
}

\section{Respuestas morfológicas y fisiológicas de dos especies de Capsicum (Capsicum annuum L. y Capsicum chinense Jacq.) bajo condiciones de déficit de agua}

Respostas morfológicas e fisiológicas de duas espécies de Capsicum (Capsicum annuum L. y Capsicum chinense Jacq.) sob condições de déficit de água

Luis F. Fernández-Zambrano ${ }^{1}$ - (10)

Liliana Corozo Quiñonez ${ }^{2}$

Álvaro Monteros Altamirano ${ }^{3}$ (a) (D)

Francisco Arteaga Alcívar ${ }^{2}$

Ramón E. Jaimez ${ }^{2 *}$

Rev. Fac. Agron. (LUZ). 2022, 39(1): e223912

ISSN 2477-9407

DOI: https://doi.org/10.47280/RevFacAgron(LUZ).v39.n1.12
${ }^{1}$ Ministerio de Agricultura y Ganadería. Ecuador.

${ }^{2}$ Universidad Técnica de Manabí. Facultad de Ingeniería Agronómica. Provincia Manabí Ecuador.

${ }^{3}$ Instituto Nacional de Investigaciones Agropecuarias. Estación Experimental Santa Catalina

Recibido: 31-08-2021

Aceptado: 19-11-2021

Published: 21-01-2022

\section{Crop Production}

Associate editor: Dr. Jorge Vilchez-Perozo

\section{Keywords:}

Growth

Nitrogen

Pepper

Drought tolerance

\begin{abstract}
Drought and water scarcity, effects from ongoing climate change, are between main limitations in agricultural production. In this sense, this study aimed to compare the differences morphological and physiological responses between local cultivars of Capsicum annuum L. and Capsicum chinense Jacq under WD conditions. After 20 days of being transplanted and maintained with adequate irrigation and fertilization, in a randomized block design, plants of four local cultivars ( 2 of $C$. annuum and 2 of $C$. chinense) were subjected to two treatments: WD consisting of 14 days without irrigation, and plants watered every three days. The relative water content (RWC), root volume, leaf area, specific leaf area, dry weight of the different organs and leaf nitrogen concentration were measured. The results show that, under conditions of WD, plants of $C$. annuиm and $C$. chinense decreases significantly leaf RWC, root volumes, total growth and leaf nitrogen concentration. In the case of $C$. annuum, the WD affected production, which varied between cultivars. It seems that the mobilization of photoassimilates towards fruits is a strategy for a higher production for some cultivar of $C$. апnиит as demonstrated in the cultivar ECU-2254b, however, it was the cultivar that showed the lowest RWC in both conditions of water availability. The cultivar of $C$. chinense ECU-2241, showed a better tolerance to WD presenting greater root growth and greater RWC.
\end{abstract}




\section{2-7| Rev. Fac. Agron. (LUZ). 2022, 39(1): e223912. January - March. ISSN 2477-9407.}

\section{Resumen}

La sequía y la escasez de agua, producto del cambio climático en curso, están entre las principales limitaciones en la producción agrícola. En este sentido, esta investigación tuvo como objetivo comparar las diferencias en las respuestas morfológicas y fisiológicas entre cultivares locales de Capsicum annuum L. y Capsicum chinense Jacq en condiciones de déficit hídrico. En un diseño de bloques al azar, luego de 20 días de ser trasplantadas y mantenidas con riego y fertilización adecuada, plantas de cuatro cultivares locales $(2 \mathrm{de}$ C. annuит y 2 de C. chinense) fueron sometidas a dos tratamientos: déficit hídrico consistente en 14 días sin riego, y plantas regadas cada tres días. Se midió el contenido relativo de agua (RWC), volumen de raíces, área foliar, área foliar específica, peso seco de los diferentes órganos y concentración de nitrógeno foliar. Los resultados muestran que, en condiciones de déficit hídrico, las plantas de $C$. annuит y $C$. chinense disminuyen significativamente el RWC foliar, el volumen de raíces, el crecimiento total y la concentración de nitrógeno foliar. En el caso de C. annuиm, el déficit hídrico afectó la producción, que varió entre cultivares. Al parecer la movilización de fotoasimilados hacia frutos es una estrategia para una mayor producción en algunos cultivares de $C$. annuиm como se demuestra en el cultivar ECU-2254b, sin embargo, fue el cultivar que presentó menor RWC en ambas condiciones de disponibilidad de agua. No hubo diferencias significativas entre cultivares en la concentración de nitrógeno foliar en condiciones de déficit hídrico El cultivar de C. chinense ECU-2241, mostró una mejor tolerancia al déficit hídrico al presentar mayor crecimiento radicular y mayor RWC.

Palabras claves: crecimiento, nitrógeno foliar, pimiento, tolerancia a la sequía

\section{Resumo}

A seca e a escassez de água, efeitos das mudanças climáticas em curso, são as principais limitações na produção agrícola. Nesse sentido, o presente trabalho visa comparar as diferenças nas respostas morfológicas e nas relações hídricas entre locais, cultivares de Capsicum annuum L. e Capsicum chinense Jacq sob condições de déficit hídrico. Após 20 dias do transplante e manutenção adequada de irrigação e fertilização, plantas de quatro local cultivares (2 de $C$. annuum and 2 de $C$. chinense) foram submetidas a dois tratamentos: déficit hídrico de 14 dias sem irrigação e plantas irrigadas a cada três dias, em um delineamento de blocos ao acaso. Foram avaliados o conteúdo relativo de água (RWC), o volume da raiz, a área foliar, a área foliar específica e o peso seco dos diferentes órgãos e concentração de nitrogênio na folha. Os resultados mostraram que, em condições de déficit hídrico, as plantas de $C$. annuum e $C$. chinense diminuem o RWC na folha, no volume das raízes, no crescimento total e na concentração de nitrogênio na folha. No caso de $C$. annuum, o déficit hídrico afetou a produção, que variou entre as cultivares. Parece que a mobilização de fotoassimilados para os frutos é uma estratégia para uma maior produção de $C$. annuum como demonstrado pelo cultivar ECU-2254b, porém foi a cultivar que apresentou o menor RWC em ambas as condições de disponibilidade hídrica. A cultivar de $C$. chinense ECU-2241, apresentou melhor tolerância ao déficit hídrico por apresentar maior crescimento radicular e maior RWC.

Palavras-chave: crescimento, nitrogênio foliar, pimenta, tolerância à seca

\section{Introduction}

As a result of the increase of greenhouse gases in the atmosphere, an increase in global temperature is predicted, which may lead to the desiccation of many regions due to increases in evaporation and decreases in total annual precipitation (Kunapala et al., 2020 Kweku et al., 2018). Drought and water shortages are one of the main limitations in agricultural production, as a consequence, today it is important to understand the adaptation and tolerance responses of different cultivars to these conditions. The water deficit (WD) reduces stem and root growth, leaf area, specific leaf weight and plant biomass (Gray \& Brady, 2016) and leads to changes in physiological aspects (Lawlor \& Tezara, 2009). The responses of plants under conditions of WD are complex and diverse and although physiological studies at various scales are conducted to understand the mechanisms involved, these have not been fully elucidated (Zandalinas et al., 2018), so the information that can be obtained is basic in breeding programs in order to achieve cultivars tolerant to water deficiencies.

The Capsicum genus is made up of about 35 species, of which five species (Capsicum annuum L., Capsicum frutescens L., Capsicum pubescens, Capsicum chinense Jacq and Capsicum baccatum L.) have been domesticated (Bosland \& Votava, 2012). The Food and Agriculture Organization of the United Nations (FAO) for the year 2019 reported that the area sown with chili and peppers worldwide amounted to about 2 million ha with an approximate production of 38 million t. Of this, 238.271 ha were planted in the American continent producing $4.942 .458 \mathrm{t}$ (FAO, 2021). C. annuum and C. chinense are among the most widely cultivated species in the American continent.

Several species of Capsicum are sensitive to WD (Jaimez et al., 2000; Gonzalez-Dugo et al., 2007, Macias-Bobadilla et al., 2020) and the effect of this deficit considerably reduces production if it occurs in the flowering period and the beginning of fruit formation (Jaimez et al., 2000, Yang et al., 2018). In addition, in the seedling stage in open field conditions, the decrease in water availability considerably affects growth and can even lead to plants' death. In the Capsicum genus, the low availability of water in the soil causes a decrease in plant height, basal diameter, root volume and biomass (May-Lara et al., 2011) significant reductions in leaf water potential and yield (Jaimez et al., 1999; Jaimez et al., 2000; Mardani et al., 2017;) reductions of $\mathrm{CO}_{2}$ assimilation and electron transport rates (Campos et al., 2014, Martinez-Acosta et al., 2020) and reductions of nitrogen (N) uptake that influences the reduction of amino acids involved in different metabolic pathways (Serret et al., 2018).

In relation to $C$. annuum and $C$. chinense there is information on responses to the WD of commercial cultivars, but little information exists on local cultivars, which limits the understanding of the variations of response to $\mathrm{WD}$ as a function of the genotypic variability in these species. Therefore, it is necessary to understand the morphological responses and nutrients intake in conditions of WD of these species, in order to be considered in future breeding programs. Then, the objective of this study was to evaluate the morphological and physiological differences response of local cultivars of $C$. annuum L. and C. chinense Jacq. under conditions of WD in order to select possible drought tolerant cultivars.

\section{Materials and methods}

The experiment was carried out under greenhouse conditions in the experimental Campus "La Teodomira" of the Technical University of Manabí, Province of Manabí, Ecuador (01 ${ }^{\circ} 09^{\prime} 51^{\prime}$ S and $80^{\circ}$ 
23 '24" W) at an altitude of 60 m.a.s.1. The average temperature in the greenhouse was $25^{\circ} \mathrm{C}$ and a relative humidity of $82 \%$.

Local cultivars: Two cultivars of $C$. annuum L. and two of $C$. chinense Jacq.) were evaluated. The seeds of the cultivars were obtained from the Genebank of the National Institute of Agricultural Research (INIAP) of Ecuador. The cultivars of $C$. annuum were the ECU-2254b and ECU-2254c collected in the province of El Oro and for $C$. chinense Jacq the cultivars ECU-2239a and ECU-2241 were collected in the province of Manabí (name of cultivars are codes of INIAP). The selection of cultivars was made based on previous information of high productions (greater than 2000 kg.ha-1) (Loor \& Muñoz, 2019). The seeds were sown in plastic trays with 32 cells (54 cm long x $28 \mathrm{~cm}$ wide and $5.52 \mathrm{~cm}$ deep) using peat as substrate. Subsequently, they were transplanted 28 days after sowing to 40 $\mathrm{cm}$ high $\times 30 \mathrm{~cm}$ with polyethylene bags with previously prepared substrate with a mixture of $50 \%$ organic matter based on bovine manure, $25 \%$ sowing soil and 25\% from a carbonated source (crushed peanut shell from the region). Polyethylene bags were located in a randomized block design, which consisted of eight treatments; 2 irrigation (plants irrigated and plant without irrigation) $\mathrm{x}$ four cultivars (two $C$. annuum cultivars and two cultivars of $C$. chinense) and 4 repetitions (blocks) with a total of 160 plants in an area of 120 $\mathrm{m}^{2}$. Each experimental unit had 5 plants.

Before inducing the treatments, the seedlings were watered every two days and each plant was fertilized 10 days after transplantation (dat) with $40 \mathrm{~g}$ of compound commercial fertilizer (12 N - $11 \mathrm{P}-18 \mathrm{~K}$ ) and in a leaf way with a water-soluble fertilizer $(24 \mathrm{~N}-18 \mathrm{P}-13 \mathrm{~K})$ in proportions of $0.5 \mathrm{~g}$. $\mathrm{L}^{-1}$ of water every three days. At 20 days after transplanting (dat) the treatments began: WD that consisted of 14 days without irrigation and watered every three days to maintain soil close to field capacity.

Fourteen days after starting the water experiment, 4 plants were taken per treatment for physiological and morphological measurements. The relative water content of the leaf (RWC) was determined from leaf cuttings (10 squares of leaves were cut from the plants of each cultivar) and weighed (fresh weight, FW) in an analytical balance. Once weighed, they were placed to saturate in petri dishes with distilled water for a time of four hours; after this period, leaf cuttings were taken out the surface moisture was removed with an absorbent paper were weighed (saturation weight, SW) and placed in an oven for 48 hours at $65^{\circ} \mathrm{C}$, later the dry weight (DW) was determined. The RWC was calculated as follow: (FW-DW/SW-
DW) *100 (Sanders \& Arndt, 2012). The volume of roots (RV) was determined by carefully taking the roots out of the substrate, removing the soil and introduced them into a cylinder of known volume of water -the displaced water content determined the volume of the roots. The leaf area (LA) was measured for each genotype with a model LI-3100 leaf area meter. The determination of the specific leaf area (SLA) was calculated by dividing the leaf area between the dry weight of the leaf. The dry weight of root (PR), stem (PT) and leaves (PH) was determined by separating each of its parts and placed in an oven at $65^{\circ} \mathrm{C}$ for 72 hours and once dried they were weighed. The Kjeldahl method was used for the determination of the $\mathrm{N}$ concentration in the leaves.

A one-way analysis of variance was performed. For the comparison of means, the Tukey test was used at $0.05 \%$. The data were expressed as mean values \pm standard error. Linear relationships were made between some variables.

\section{Results and discussion}

\section{Relative water content (RWC)}

The analysis of variance shows that there was a significant effect on the irrigation factor for all traits with exception of SLA while for cultivar factor there was significant differences for RWC, root weight (RW) and stem weight (SW) (table 1). The non-irrigated plants of all cultivars presented lower significant RWC, in relation to the irrigated plants (figure 1). In plants without irrigation the variations were between 37\% (cultivar ECU-2254b) and 53.9\% (cultivar ECU$2254 \mathrm{c}$ ). In irrigated plants there were no significant differences between cultivars, the values ranged between $61.8 \%$ and $80 \%$.

There is a tendency that the cultivars with the highest RWC in irrigated plants are those that also present the highest RWC in the treatment without irrigation; this variable could be evaluated in other cultivars. Other results differ about the effect of the WD on the RWC probably due to the fact that the number of days in WD changes e.g. Serret et al. (2018) found no significant differences in the RWC of $C$. annuum due to the WD, probably because the deficit was evaluated in plants that were watered every 3 days, and in the case of our study the length of the deficit was 14 days. On the other hand, significant reductions in RWC in C. annuum and C. chinense have been obtained as the availability of water in the soil decreases both in the vegetative stage and in flowering and fruiting, however C. chinense showed higher RWC (Okunlola et al., 2017).

Table 1. Analysis of the variance for relative water content (RWC), specific leaf area (SLA), root volume (RV), root weight (RW), stem weight (SW), leaf weight (LW) and percentage of leaf nitrogen $(\mathrm{N})$.

\begin{tabular}{|c|c|c|c|c|c|c|c|}
\hline F.V. & RWC & SLA & RV & RW & SW & LW & $\mathbf{N}$ \\
\hline Model & $5946.67 *$ & 40380.56 & $872.08 * *$ & 17.48 & $148.37 *$ & $127.21 *$ & $12.40 *$ \\
\hline Block & 44.85 & 1570.55 & 14.08 & 0.29 & 11.07 & 0.13 & 0.03 \\
\hline Irrigation & $4719.85^{*}$ & 11359.47 & $486^{* *}$ & $5.9^{*}$ & $51.33^{* *}$ & $101.27 * *$ & $11.67^{*}$ \\
\hline Cultivar & $1078.47 *$ & 10161.4 & $360.67 * *$ & 8.59 & $72.13 * *$ & 13.14 & 0.20 \\
\hline Irrigation*Cultivar & 103.5 & 17289.15 & 11.33 & 2.7 & 13.83 & 12.66 & 0.42 \\
\hline Error & 728.9 & 58143.76 & 171.25 & 13.65 & 42.25 & 47.81 & 0.83 \\
\hline Total & 6675.57 & 98524.32 & 1043.33 & 31.13 & 190.62 & 175.02 & $\underline{13.23}$ \\
\hline
\end{tabular}

The displayed value is the sum of squares. Significance $\mathrm{a} * * \mathrm{P}<0.001 . * \mathrm{P}<0.05$ 


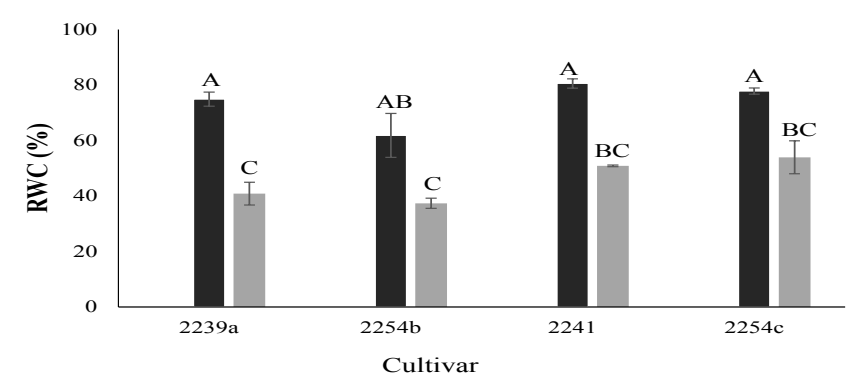

Figure 1. Relative leaf water content (RWC) in cultivars of Capsicum annuum (ECU-2254b and ECU-2254c) and Capsicum chinense (ECU-2239a and ECU-2241) with irrigation (black bars) and without irrigation (gray bars). Lines in bars are the standard errors. Different letters are significant differences $(\mathrm{P}<0.05)$ according to Tukey test.

\section{Specific leaf area}

The analysis of variance shows that there are no differences in the effects of irrigation and cultivars (table 1). However, there is a tendency for cultivars to present lower SLA with WD (figure 2). For example, the SLA of ECU-2239a decreased by 40\%, while ECU2241 the decrease was $27 \%$ and ECU-2254c only $9 \%$ with respect to the SLA of irrigated plants.

The results suggest that $C$. chinense cultivars have the tendency to present lower SLA than $C$. annuum cultivars, as a strategy to avoid greater areas of transpiration, Okunlola et al. (2017) and Serret et al. (2018) reported significant decreases of SLA in $C$. annuum under moderate conditions of WD (irrigation every three days). Although Martinez-Acosta et al. (2020) found in C. annuum plants under soil WD between 75 and $25 \%$, that the weight and the leaf area decreased, however, the decrease in weight was greater, maintaining higher SLA until the 80 days. Subsequently, the decrease in SLA is similar and significantly lower in both conditions with respect to plants with $100 \%$ water availability. When the WD develops slowly, changes occur in development processes that have various effects on growth. Although the leaf area is important, since a greater light uptake depends on it, a high leaf expansion can negatively affect adaptation to the low availability of water due to a greater transpiratory surface (Wang et al., 2017).

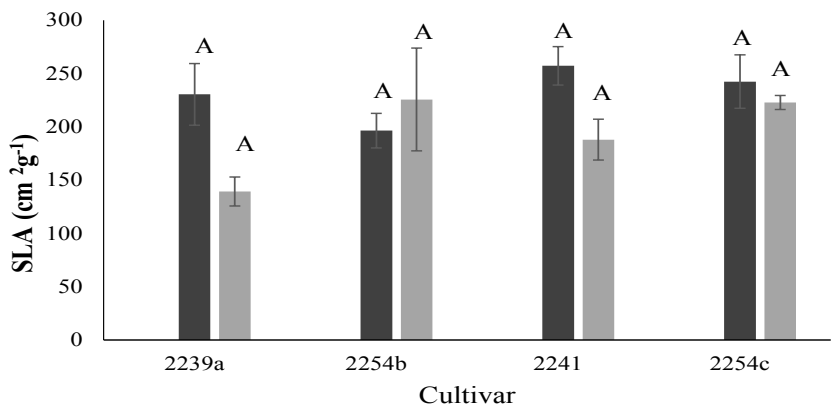

Figure 2. Specific leaf area (SLA) in cultivars of Capsicum annuum (ECU-2254b and ECU-2254c) and Capsicum chinense (ECU-2239a and ECU-2241) with irrigation (black bars) and without irrigation (gray bars). Lines in bars are the standard error. Different letters indicate significant differences $(\mathrm{P}<0.05)$ according to Tukey test.

\section{Root volume}

The available water content in the soil for the plants, influenced the significant responses both for cultivars and for the irrigation factor (table 1). The cultivar of $C$. chinense ECU-2241, was the one that presented the highest volume of roots in both conditions of water content, while the cultivar of $C$. annuum ECU-2254b the lowest (figure 3). In the conditions of WD, all the cultivars decreased the root volumes, being only significant for the cultivar of $C$. chinense ECU-2239a. The cultivar presenting the greatest decrease in root volume (57\%) was $C$. chinense ECU-2241, while the cultivar ECU$2254 \mathrm{~b}$ the least $(46 \%)$. Under irrigation conditions, $C$. chinense cultivars presented the highest root volumes. A linear relationship $\left(r^{2}=0.76 \%\right)$ was found between root volume and RWC (figure 4).

The linear relationship between the volume of roots and the RWC seems to indicate that in Capsicum a greater surface of root contact with the soil ensures a greater amount of water in the leaves and therefore apparently a lower water stress. This trend of greater amount of root volume could be used as a variable that indicates a greater tolerance to WD. It is also known in other Solanaceae species (tomato) that the WD leads to a reduction in the area of the root xylem, decreasing the water potential and lead to decreases in the leaf stomatal conductance (Hernandez-Espinoza \& BarriosMacias, 2020). The evaluation of several root variables could then be used as a criterion for improvement programs; studies with larger number of cultivars should be carried out to verify these trends.

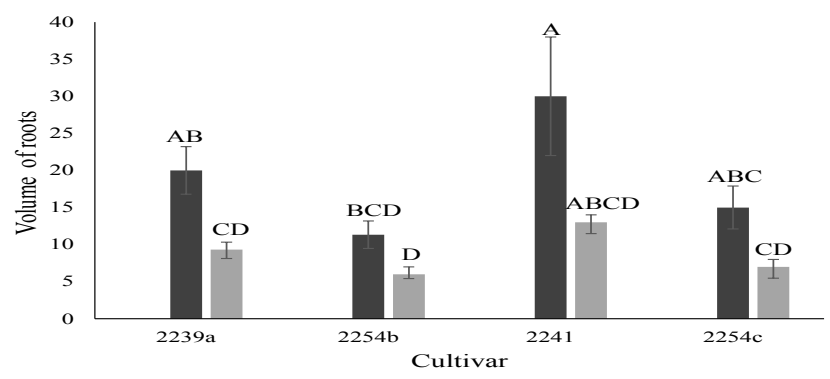

Figure 3. Volume of roots in cultivars of Capsicum annuum (ECU-2254b and ECU-2254c) and Capsicum chinense (ECU-2239a and ECU-2241) with irrigation (black bars) and without irrigation (gray bars). Lines in the bars are the standard errors. Different letters indicate significant differences $(\mathrm{P}<0.05)$ according toTukey test.

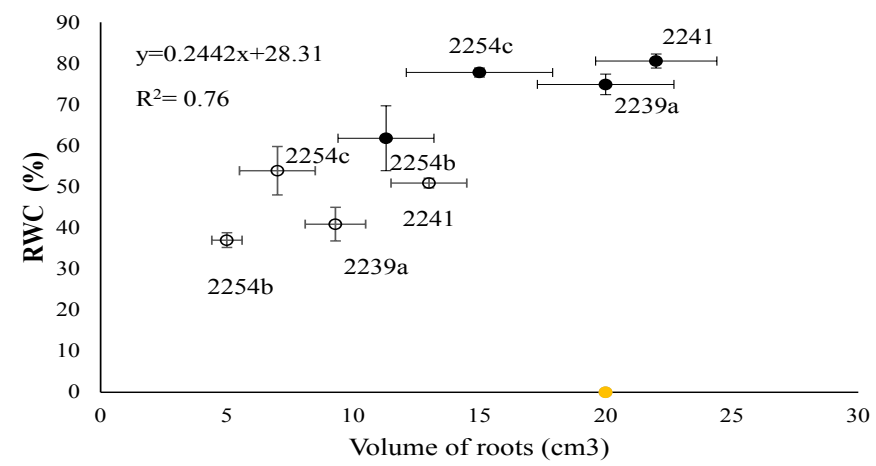

Figure 4. Relationship between root volume and relative water content (RWC) in cultivars of Capsicum annuum (ECU-2254b and ECU-2254c) and Capsicum chinense (ECU-2239a and ECU-2241) with irrigation (black dots) and without irrigation (no fill). Vertical and horizontal lines are the standard errors. 


\section{Total biomass}

The local cultivars of $C$. chinense presented the lowest accumulations of total biomass under irrigation conditions, presenting ECU-2239a, with the least significant accumulation (figure 5). Under conditions of WD there were no significant differences in the dry weight reached between the cultivars, while those of C. annuum, despite presenting the highest accumulation of biomass, were the most affected by the WD. Cultivars ECU-2254b and ECU-2254c under the deficit treatment only reached 55 and $58 \%$ and their decreases were significant $(\mathrm{P}<0.05)$ with respect to the total dry weight obtained under irrigation conditions, while the cultivars of $C$ chinense ECU-2239a and ECU-2241 reached 87 and $60 \%$ respectively of the dry weight in WD conditions in relation to the irrigated plants.

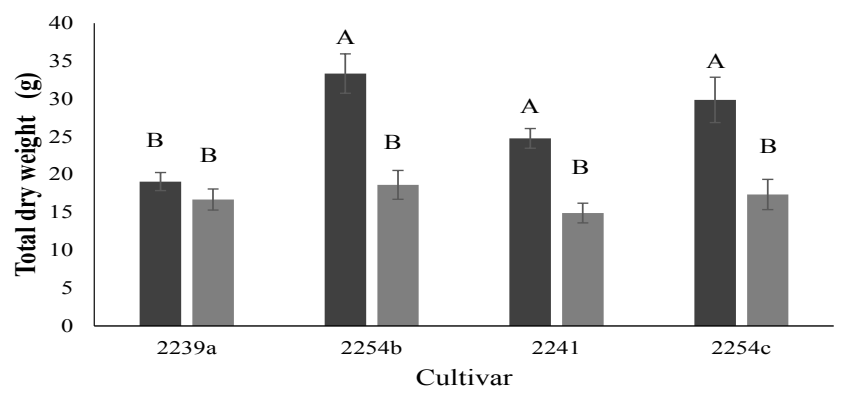

Figure 5. Total dry weight of Capsicum annuum cultivar plants (ECU-2254b and ECU-2254c) and Capsicum chinense (ECU-2239a and ECU-2241) with irrigation (black bars) and without irrigation (gray bars). The lines are the standard errors.

\section{Weight of the different organs}

In relation to the weight distribution among the different organs, no significant differences were found $(\mathrm{P}<0.05)$ due to the effects of the irrigation factor or cultivar for the RW or LW, but significance was found in the SW for both the cultivar and for irrigation (table 1 ), where the least significant weight of the watered plants was presented by the cultivar ECU-2239a (figure $6 \mathrm{~A}$ ). The leaves in all cultivars maintained the highest amounts of weight in both conditions of water availability, followed by the stem and the root (figure $6 \mathrm{~A}, \mathrm{~B}$ ). C. annuum cultivars presented fruit production, being ECU-2254b the one with the highest significant production both under irrigation conditions and in WD (figure $6 \mathrm{~A}, \mathrm{~B}$ ).

All organs presented lower weight under conditions of WD (figure $6 \mathrm{~B}$ ) e.g. fruit production in $C$. annuum cultivars was the most affected, with decreases close to $80 \%$ in both cultivars with relation to production in irrigated plants (figure $6 \mathrm{~A}, \mathrm{~B}$ ). The lower productions also implied an increase in the weight distribution towards leaves and stems in both cultivars of $C$. annuum under WD. The WD did not influence the distribution of assimilates between the area and the roots in any of the cultivars (figure 7). In the cultivars of $C$. chinense, the lowest values were presented in the aerial part/root weight ratio in the two conditions of water availability (figure 7).

Although the WD did not influence the distribution of assimilates between the aerial parts and the roots in any of the cultivars, in the cultivars of $C$. chinense the lowest values were presented in the relation weight aerial part / root weight under the two conditions of water availability, which indicates that in this species a greater investment of photoassimilates towards root growth is likely, which
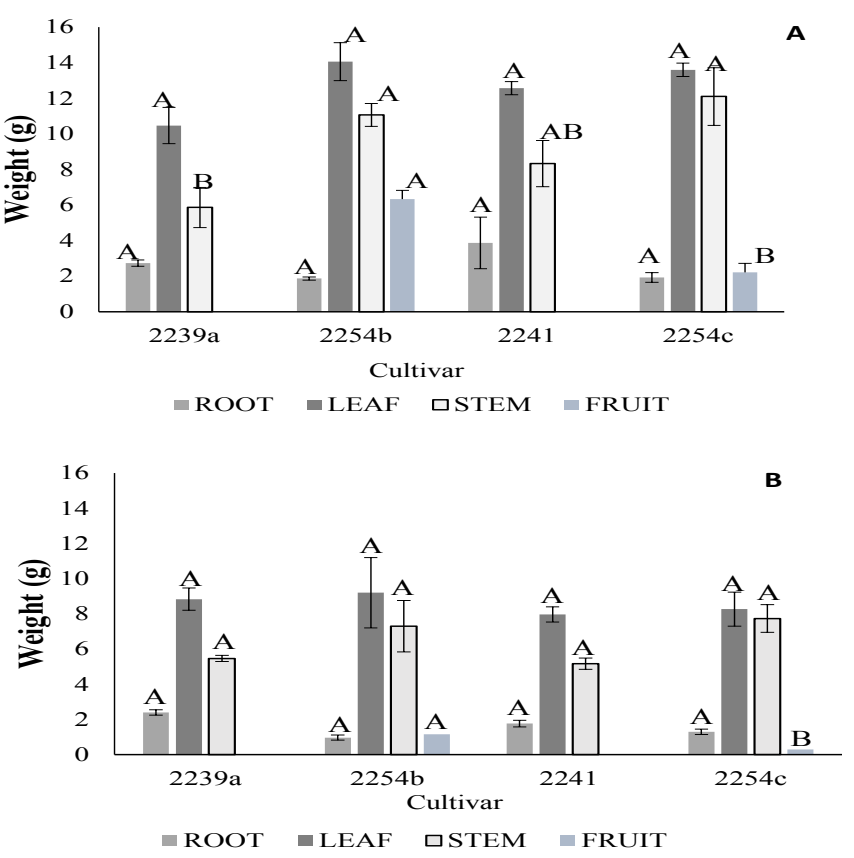

Figure 6. Final dry weight of root leaf, stem and fruit of Capsicum annuum (ECU-2254b and ECU-2254c) and Capsicum chinense (ECU-2239a and ECU2241) with irrigation (A) and without irrigation (B). Lines in the bars are the standard errors. Different letters indicate significant differences $(\mathrm{P}<\mathbf{0 . 0 5})$.

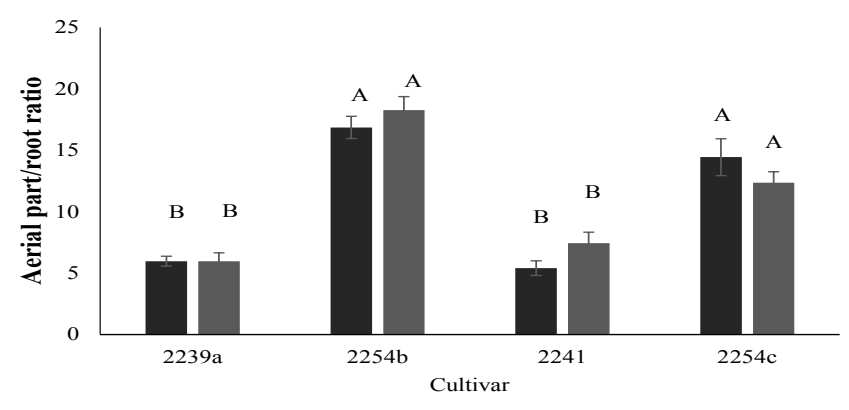

Figure 7. Relationship between aerial part weight (stems and leaves) and root weight in cultivars of Capsicum annuum (ECU-2254b and ECU-2254c) and $C$ Capsicum chinense (ECU-2239a and ECU-2241) with irrigation (black bars) and without irrigation (gray bars). Lines in the bars are the standard errors.

could ensure a greater amount of water intake. Thus, $C$. chinense plants maintain the development of their roots in search of water in deeper areas of the soil (Potters et al., 2007). However, this will depend on the efficiency of the water intake by the roots (HernandezEspinoza \& Barrios-Macias, 2020). Cultivars of C. annuum, on the contrary, have a greater investment towards the growth of the aerial part (leaves and stems). It seems that both species have different initial strategies for the distribution of assimilates, an aspect that should be corroborated with a greater number of cultivars in both species. In the cultivars of $C$. chinense, the percentage distribution of weight between the organs remained similar in both conditions of water availability, which indicates that despite the decrease in water, a sink force was maintained the same as in conditions of irrigation. These results are similar to those reported by Jaimez (2000), where cultivars of $C$. chinense under conditions of different irrigation 
frequencies (every 3, 6 and 9 days) presented a trend of greater accumulation of dry matter with greater irrigation frequency, but the distribution of dry matter to the different organs remained relatively constant, independent of the frequency of irrigation. It seems that the greater investment towards root growth offers a greater possibility of water uptake to $C$. chinense plants and therefore they are less affected in terms of growth.

All organs presented lower weight under conditions of WD, which implies that there were lower rates of photosynthesis (MartinezAcosta et al., 2020). Under WD condition, fruit production in $C$. annuum cultivars was the most affected, with decreases close to $80 \%$ in both cultivars. Similar trends of water-deficient and irrigated plants have been reported by Dorji et al. (2005). The decreases in fruit production may be due to a higher number of floral abortions and small fruits. Drought stress has been shown to decrease yield, and at the same time produce senescence of leaves (Vashi et al., 2020). A higher fruit production of the ECU-2254b initially under water limitations indicates a greater investment of photoassimilates towards fruit production, an important characteristic at times of less water availability. It is probable that in the ECU-2254b a greater quantity of photoassimilates is distributed towards fruits, which gives it greater productivity both under irrigation conditions and under WD.

The lower productions in WD also implied an increase in the weight distribution towards leaves and stems in both cultivars of $C$. annuum. Both cultivars of $C$. chinense did not show fruit production, so it is necessary to evaluate the changes in the distribution of assimilates under conditions of WD. It is known in C. chinense that under field conditions at average temperatures of $28^{\circ} \mathrm{C}$ and without water limitations, the fruits have the highest relative growth rates between 76 and 86 days after transplanting (Jaimez \& Rada, 2016). In this experiment, the plants were kept up to 60 days; therefore, it is important to carry out future experiments including the production phase.

\section{Leaf nitrogen concentration (N)}

The analysis of variance showed that there is a significant effect of irrigation on the leaf $\mathrm{N}$ concentration (table 1). Under conditions of WD, the $\mathrm{N}$ content in plants decreased significantly $(\mathrm{P}<0.05)$. The four cultivars showed significantly lower concentrations of $\mathrm{N}$ with respect to irrigated plants (figure 8). However, there are no differences between cultivars for each of the water conditions evaluated.

The lower significant concentrations of $\mathrm{N}$ in plants without irrigation indicate that under limited water conditions in all cultivars there was also a lower uptake of $\mathrm{N}$, probably due to lower

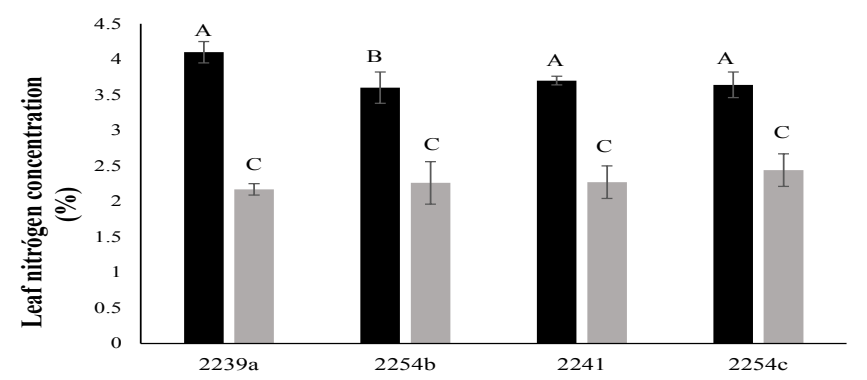

Figure 8. Nitrogen concentration of $C$ Capsicum annuum cultivars (ECU-2254b and ECU-2254c) and Capsicum chinense (ECU-2239a and ECU-2241) with irrigation (black bars) and without irrigation (gray bars), the bars are the standard errors. Different letters indicate significant differences ( $\mathrm{P}$ $<0.05)$. transpiration rates (Ismail, 2010). González-Dugo et al. (2007) explain that in general lower concentrations of $\mathrm{N}$ have been found in crop plants that are subject to WD. It is probable that lower availability of water in the soil led to a partial stomatal closure, which influenced lower rates of $\mathrm{CO}_{2}$ assimilation and transpiration rates reported in both species (Jaimez et al., 1999; Serrat et al., 2018; Martinez -Acosta et al., 2020) leading to a lower rate of uptake of $\mathrm{N}$ and also lower growth rates. The lower concentrations of $\mathrm{N}$ influence decreases in the photosynthetic capacity, which leads to lower growth rates. In three of the cultivars, the effect of the deficit led to reductions of $43 \%$ in the leaf $N$ concentration. Only cultivar ECU-2254b had reductions of $32 \%$ and maintained the highest fruit production in WD.

\section{Conclusions}

The most important aspects standing out from this research are: The higher root volume leads to a better adaptation in terms of maintaining higher RWC in irrigated and non-irrigated conditions, with the trend that cultivars with higher RWC and root volume in watered plants are those that also present the highest root volume and RWC values in the treatment without irrigation.

There is a greater distribution of assimilates towards the roots in cultivars of $C$. chinense, while cultivars of $C$. annuum mobilize more quantity of assimilates to the stem and fruit formation in both conditions of water availability (WD and without WD). Although there is lower growth due to the WD, the differences between cultivars in the aerial / root biomass ratio did not change. The decrease in root growth during periods of WD also influences a lower uptake of $\mathrm{N}$ that consequently influences lower growth rates.

The cultivar of $C$. annuum ECU-2254b could be selected for having a higher production under WD while the cultivar of $C$. chinense ECU-2241, shows a better tolerance to WD by presenting greater root growth and greater RWC in deficit conditions hydric. The responses in Capsicum appear to vary between cultivars within the same species and between species.

\section{Cited literature}

Bosland, P. W., \& Votava, E. J. (2012). Peppers: vegetable and spice capsicums ( $2^{\text {nd }}$ edition). Cabi Publishing, Oxon. 204 p.

Campos, H., Trejo, C., Peña-Valdivia, C. B., García-Nava, R., Conde-Martínez, F. V., \& Cruz-Ortega, M. R. (2014). Stomatal and non-stomatal limitations of bell pepper (Capsicum annuиm L.) plants under water stress and re-watering: Delayed restoration of photosynthesis during recovery. Environmental and experimental botany,98,56-64. www. sciencedirect.com/science/article/pii/S0098847213001706

Dorji, K., Behboudian, M H.,\& ZegbeJ. A. (2005). Water relations,growth, yield and fruit quality of hot pepper under deficit irrigation and partial rootzone drying. Scientia Horticulturae, 104(2), 137-149 https://doi. org/10.1016/j.scienta.2004.08.015

FAO (Organización de las Naciones Unidas para la Alimentación y la Agricultura). (2021). FAOSTATS. Producción, exportaciones $e$ importaciones mundiales de chiles y pimientos secos y verdes por paises. http://www.fao.org/faostat/.

González-Dugo, V., Orgaz, F., \& Fereres, E. (2007). Responses of pepper to deficit irrigation for paprika production. Scientia Horticulturae, 114(2), 77-82. https://doi.org/10.1016/j.scienta.2007.05.014

Gray, S. B., \& Brady, S. M. (2016). Plant developmental responses to climate change. Developmental biology,419(1), 64-77. https://doi. org/10.1016/j.ydbio.2016.07.023

Hernandez-Espinoza, L. H., \& Barrios-Masias, F. H. (2020). Physiological and anatomical changes in tomato roots in response to low water stress. Scientia Horticulturae, 265, 109208. https://doi.org/10.1016/j. scienta.2020.109208

Ismail, S. M. (2010). Influence of deficit irrigation on water use efficiency and bird pepper production (Capsicum annuиm L.). Meteor. Environ. Arid Land Agric. Sci, 21(2) 29-43 https://doi.org/https://10.4197/Met.21-2.3 
Jaimez, R. (2000). Dinámica de crecimiento y distribución de materia seca en ají dulce (Capsicum chinense Jacq) bajo condiciones de déficit de agua. Agronomía Tropical, 50(2), 189-200.

Jaimez, R. E., \& Rada, F. (2016). Gas exchange, growth, flowering and fruit production in sweet pepper (Capsicum chinense jacq) along a thermal gradient determined by altitudinal differences in a tropical region. Experimental Agriculture, 52(2), 251-265. https://doi.org/10.1017/ S0014479715000071

Jaimez, R. E., Rada, F., \& Garcia-Núnez, C. (1999). The effect of irrigation frequency on water and carbon relations in three cultivars of sweet pepper (Capsicum chinense Jacq), in a tropical semiarid region. Scientia Horticulturae, 81(3), 301-308. https://doi.org/10.1016/S03044238(99)00017-5

Jaimez, R. E., Vielma, O., Rada, F., \& García-Núñez, C. (2000). Effects of WD on the dynamics of flowering and fruit production in Capsicum chinense Jacq in a tropical semiarid region of Venezuela. Journal of Agronomy and Crop Science, 185(2), 113-119. https://doi.org/10.1046/ j.1439-037x.2000.00414.x

Kweku, D., Bismark, O., Maxwell, A., Desmond, K., Danso, K., OtiMensah, E., Quachie, A., \& Adormaa, B. (2018). Greenhouse Effect: Greenhouse Gases and Their Impact on Global Warming. Journal of Scientific Research and Reports, 17(6), 1-9. https://doi.org/10.9734/ JSRR/2017/39630

Konapala, G., Mishra, A.K., Wada, Y. \& Mann, M. (2020) Climate change will affect global water availability through compounding changes in seasonal precipitation and evaporation. Nature Communications 11, $3044 \mathrm{https}$ :// doi.org/10.1038/s41467-020-16757-w

Lawlor, D. W., \& Tezara, W. (2009). Causes of decreased photosynthetic rate and metabolic capacity in water-deficient leaf cells: a critical evaluation of mechanisms and integration of processes. Annals of botany, 103(4), 561-579. https://doi.org/https://doi.org/10.1093/aob/mcn244

Loor, H. V. \& Muñoz S. 2019 Caracterización morfológica de las accesiones del germoplasma de Capsicum del Instituto Nacional de Investigaciones Agropecuarias Tesis Ingeniería Agronómica. Universidad Técnica de Manabí $56 \mathrm{p}$.

Macias-Bobadilla, I., Vargas-Hernandez, M., Guevara-Gonzalez, R. G., RicoGarcia, E., Ocampo-Velazquez, R. V, \& Torres-Pacheco, I. (2020). Differential Response to WD in Chili Pepper (Capsicum annuum L.) Growing in Two Types of Soil Under Different Irrigation Regimes. Agriculture, 10(9), 381. https://doi.org/10.3390/agriculture10090381

Mardani, S., Tabatabaei, S. H., Pessarakli, M., \& Zareabyaneh, H. (2017). Physiological responses of pepper plant (Capsicum annuum L.) to drought stress. Journal of Plant Nutrition,40(10),1453-1464. https:// doi.org/10.1080/01904167.2016.1269342

Martinez-Acosta, E., Lagunes-Espinoza, L. C., Castelán-Estrada, M., LaraViveros, F., \& Trejo, C. (2020). Leaf gas exchange and growth of
Capsicum annuum var. glabriusculum under conditions of flooding and WD. Photosynthetica, 58(3), 873-880. https://doi.org/10.32615/ ps.2020.032

May-Lara, C., Pérez-Gutiérrez, A., Ruiz-Sánchez, E., Ic-Caamal, A. E., \& García-Ramírez, A. (2011). Efecto de niveles de humedad en el crecimiento y potencial hídrico de Capsicum chinense Jacq. y su relación con el desarrollo de Bemisia tabaci Genn. Tropical and subtropical agroecosystems, 14(3), 1039-1045.

Okunlola, G. O., Olatunji, O. A., Akinwale, R. O., Tariq, A., \& Adelusi, A. A. (2017). Physiological response of the three most cultivated pepper species (Capsicum spp.) in Africa to drought stress imposed at three stages of growth and development. Scientia Horticulturae, 224,198-205. https://doi.org/10.1016/j.scienta.2017.06.020

Potters, G., Pasternak, T. P., Guisez, Y., Palme, K. J., \& Jansen, M. A. K. (2007). Stress-induced morphogenic responses: growing out of trouble? Trends in plant science, 12(3), 98-105. https://doi.org/10.1016/j. tplants.2007.01.004

Sanders G.J., Arndt, S.K. (2012) Osmotic Adjustment Under Drought Conditions. In: Aroca, R. (eds) Plant Responses to Drought Stress. Springer, Berlin, Heidelberg. https://doi.org/10.1007/978-3-642-32653-0 8

Serret, M. D., Yousfi, S., Vicente, R., Piñero, M. C., Otálora-Âlcón, G., Del Amor, F. M., \& Araus, J. L. (2018). Interactive effects of CO2 concentration and water regime on stable isotope signatures, nitrogen assimilation and growth in sweet pepper. Frontiers in plant science, 8 , 2180. https://doi.org/https://doi.org/10.3389/fpls.2017.02180

Vashi, H. D., Patel, P. P., \& Bardhan, K. (2020). Growth and physiological responses of vegetable crops to WD stress. Journal of Experimental Agriculture International, 91-101. https://doi.org/10.9734/jeai/2020/ v42i530523

Wang,H., Sánchez-Molina, J.A., Li, M., Berenguel, M., Yang, X. T., \& Bienvenido, J. F. (2017). Leaf area index estimation for a greenhouse transpiration model using external climate conditions based on genetics algorithms, back-propagation neural networks and nonlinear autoregressive exogenous models. Agricultural Water Management,183,107-115. https://doi.org/10.1016/j.agwat.2016.11.021

Yang, H., Liu, H., Zheng, J., \& Huang, Q. (2018). Effects of regulated deficit irrigation on yield and water productivity of chili pepper (Capsicum annuum L.) in the arid environment of Northwest China. Irrigation science, 36(1), 61-74. https://doi.org/https://doi.org/10.1007/s00271017-0566-4

Zandalinas, S. I., Mittler, R., Balfagón, D., Arbona, V., \& Gómez-Cadenas, A. (2018). Plant adaptations to the combination of drought and high temperatures. Physiologia plantarum, 162(1), 2-12. https://doi. org/10.1111/ppl.12540 